\title{
The formation of students' intercultural communicative competence in an English language learning environment at a non-linguistic higher school
}

\author{
Alan Pulverness - Irina I. Klimova - Olga A. Kalugina - \\ Dinara G. Vasbieva - Liliya R. Ismagilova
}

\section{DOI: $10.18355 / X L .2017 .10 .04 .31$}

\begin{abstract}
The paper investigates the formation of students' intercultural communicative competence with a specific focus on EFL teaching at a non-linguistic higher school. The purpose of this study was to develop, theoretically substantiate and assess a model of developing ICC among students in an English language learning environment. The present study was designed to test the hypothesis that the formation of ICC among EFL students at the non-linguistic higher school can be effective provided that the structure and content of ICC is made explicit and justified; the model of the formation of ICC among EFL students in a language learning environment and the technology for its implementation are developed and assessed; an example of the didactic material necessary for its implementation is provided.

Key words: intercultural communicative competence (ICC), intercultural communication, FL teaching, EFL students
\end{abstract}

\section{Introduction}

The contemporary social situation is characterized by high levels of dynamism and tension. Globalized economies, political integration and improved means of communication create the need for global citizenship, but at the same time create the need for global citizens to develop a deep feeling for their own culture and other cultures and to function successfully in an intercultural dialogue. This contradiction makes society aware of the need to revise approaches to the content and organisation of the educational process and the evaluation of its outcomes. The 'activity nature of knowledge' comes to the fore, that is, readiness to carry out specific activities successfully. To do this, the citizen of today needs to combine a high level of general education and development with an equally high professionalism in specific fields of activity. Intercultural differences in the business environment are known to lead to imbalances in decision-making mechanisms, self-organization and conflict management. According to the American Academy of Management, 55\% of international alliances and $78 \%$ of mergers and acquisitions fail within the first three years. This disintegration results not just from economic problems, but from the cultural 'discrepancy' of teams, complex organisational structures of people from different cultures and different strategic methods of doing business, in short, problems in intercultural communication. It should be noted that a competent and attentive approach to managing the cultural characteristics of employees will help to avoid failures in specific markets (Klimova, Vasbieva, 2014).

Nowadays, a successful person who speaks a foreign language is often involved in a process of business or scientific communication with representatives of other cultures. In this regard, the main requirement of foreign language education is the development of intercultural communicative competence (ICC) among students of English as a foreign language (EFL), along with grammatical competence, communicative competence and general language proficiency. ICC refers to the ability to understand cultures, including one's own, and the ability to use this understanding to communicate successfully with people from other cultures. ICC is a

XLinguae, Volume 10 Issue 4, October 2017, ISSN 1337-8384, eISSN 2453-711X 
complex combination of the student's knowledge, skills, personal qualities and abilities, ensuring the selection of adequate means and strategies for communicative and non-communicative interaction and the student's behavior in the process of intercultural interaction (Vasbieva, Kalugina, 2014: 25).A profound and meaningful mastery of a foreign language on the basis of the principle of cultural appropriateness is the basis for the future specialist to develop a value-based and tolerant attitude to the culture represented by the language studied, and to its native speakers (Sadchikova, 2009).

Developing ICC in the foreign language (FL) learning environment is an indispensable component of a future specialist's training. Russia's growing integration with the world community requires new approaches to teaching a foreign language to students majoring in Economics as they need it for their future professions. Contacts with foreign partners, which used to be occasional and had to be managed through an interpreter, have now become a regular feature of modern life (Popov, 1998). Passov (1991) claims that there is a contradiction between the increased need for improvement in the level of FL literacy and an insufficiently effective system of teaching foreign languages that does not ensure positive results. In the contemporary world, the goal of teaching foreign languages is not only about the development of specific skills, but the preparation of future specialists for an effective, meaningful and productive dialogue with representatives of other cultures. The criterion for effective intercultural communication is the achievement of mutually beneficial results.

The subject matter of the present study is the process of teaching English to EFL studentsat anon-linguistic higher school.

The scope of the study is the formation of ICC among students majoring in Economics in an English language learning environment.

The purpose of the research is to develop, theoretically substantiate and assess a model for developing ICC among students in the English language learning environment at a non-linguistic higher school.

The present study was designed to:

- test the hypothesis that the formation of ICC among EFL students at a non-linguistic higher school can be effective provided that the structure and content of ICC is made explicit and justified

- develop and assess the model of the formation of ICC among EFL students in a language learning environment and the technology for its implementation

- select the didactic material necessary for its implementation

In accordance with the subject, purpose and hypothesis of the study, the research objectives are as follows:

- to reveal, describe and justify the content and structure of ICC

- to develop and assess a model for the formation of ICC among students majoring in Economics in a language learning environment and the technology for its implementation

- to identify and justify the pedagogical conditions for the implementation of the model developed in the educational process at a non-linguistic higher school and to test their effectiveness experimentally

- to select didactic materials for its implementation

\section{Literature Review}

\subsection{Exploring the relationship between culture and language}

It is widely recognized that language and culture are closely interrelated, a view strongly advocated by Byram (1994), who has stated that language and cultural learning cannot take place independent of each other. Language is considered as 
communication between people with their own cultural norms, culture being a complex notion which includes language. Many scholars have put forward this point of view from various perspectives. For example, Kramsch (1993) was among the first to propose that the purpose of foreign language learning is "a way of making cultural statement" as well as learning "a new way of making communication", other researchers having attached great importance to culture for language understanding (Brown, 1986; Byram, 1994). According to Brown, misunderstandings may often occur between representatives of different cultures and we must learn how to deal with them in any situation when two cultures interact. Moreover, language is thought to be the most visible and available expression of any culture. In other words, culture influences language and vice versa. It is important for language teachers to integrate cultural perspectives into the syllabus of language programs. When students learn a foreign language, to some extent they become familiar with a foreign cultural system. Lum (2004) states that communication in real situations is never devoid of context, and because culture plays a role in most contexts, communication can hardly ever be said to beculture-free. The same word would obtain a different psychological response across various cultures. Disregarding cultural differences causes misunderstandings. Alyan (2011) makes a strong case for understanding and generating language in accordance with the sociocultural parameters of a specific situation, because EFL students first hone their communication skills against the background of their own culture and only then against the target language culture, and this process is the foundation for intercultural communication. Intercultural communication is related to direct communication between people from culturally diverse backgrounds. Sehlaoui (2011) claims that intercultural communication is a symbolic process in which people from different cultures create shared meanings.

\subsection{The role of Teaching ICC to EFL Students}

In the 21 st century, to communicate appropriately and effectively in a world of diverse cultures, FL learners need to develop ICC, which FL teaching is required to cultivate. Becoming linguistically competent presupposes becoming culturally competent and vice versa.

ICC is defined as the ability to communicate effectively and appropriately in various intercultural communication situations. In recent years there has been growing interest in ICC as an important research area in intercultural communication studies. ICC refers to abilities such as perceiving cultural factors because they are embodied in practical intercultural communication situations.

The notion of competence was introduced in 1965 by Chomsky, who defined it as "the speaker-hearer's knowledge of his language". Later scholars criticised his work for discounting contextual appropriateness. Building on previous studies, Hymes (1972:287) was the first to propose the term 'communicative competence' to mean: "rules of use without which rules of grammar would be useless". Rules of use are those that mirror the interdependence of language with its real context of use. Subsequently, communicative competence was further investigated by Savignon (1985: 130), who viewed it as the ability to function in a truly communicative setting in a dynamic exchange in which linguistic competence must adapt itself to the total information input, both linguistic and paralinguistic of one or more interlocutors.

Canale and Swain had (1980) first proposed their own theory of communicative competence which comprised three main competences: grammatical competence, sociolinguistic competence, and communication strategies or strategic competence. The first includes knowledge of lexical items and rules of morphology, syntax, sentence grammar, semantics, and phonology. The second consists of two sets of rules, socio-cultural rules of use and rules of discourse, knowledge of both of

XLinguae, Volume 10 Issue 4, October 2017, ISSN 1337-8384, eISSN 2453-711X 
which is crucial to interpreting utterances for social meaning particularly when "there is a low level of transparency between the literal meaning of an utterance and the speaker's underlying intention." More complex interpretations were introduced by Canale and Swain (1980) with the inclusion of sociolinguistic considerations, which paved the way for later consideration of cultural issues. The lack of a single clear paradigm of communicative competence is evident in its strong dependence on native speaker model, which actually excludes consideration of exchange between both sociocultural participants, and hints exclusively at situational aspects.

In a later version of this model, Canale $(1983,1984)$ derived some elements from sociolinguistic competence and devised a fourth component, which he called discourse competence. Thus, communicative competence consists of four components: grammatical competence (sentence level grammar), socio-linguistic competence (knowing how to use and respond to language appropriately, given the setting, the topic, and the relationships among the people communicating), discourse competence (understanding and producing the range of spoken, written and visual texts that are characteristics of a language), and strategic competence (a language user's employment of strategies to overcome difficulties when communication breakdowns occur by making the best use of what she/he knows about how a language works, in order to interpret, express, and negotiate meaning in a given context) (Walcott, 2001).

Communicative competence is seen then as the ability to generate relevant stretches of speech subject to the FL native context (Vyas, Patel, 2009). From this perspective, it is reasonable to believe that EFL teaching should help students make meaning rather than focus solely on the linguistic element. Many attempts have been made by EFL teachers in order to improve both ICC and linguistic competence. According to Vyas and Patel (2009), ICC refers to the implicit mastery of the norms of society, the unspoken rules reporting specific behaviour as acceptable or unacceptable. ICC also includes knowledge of many aspects of society and culture: forms of address, choices of register and style, differences between social and regional dialects, as well as the social values attached to these differences. To succeed in intercultural communication, it is essential to have both linguistic and cultural competences. The degree to which a learner is able to master intercultural communication skills and the ability to be a cross-cultural mediator largely determine the formation of the student's ICC. According to I.L. Pluzhnik: “... it [ICC] is a functional ability to understand the views and opinions of representatives of another culture, adjust their behavior, overcome conflicts during the communication process, recognize the right to the existence of different values, norms of conduct ...”(Vasbieva, 2015: 40).

When applied to FL teaching, cultural competence focuses on the knowledge and skills required to develop effective strategies to better serve students from culturally diverse backgrounds. Dillerand and Moule (2005) argue that ICC is the ability to pinpoint cultural diversity and develop empathy, i.e. the ability to understand and share another person's experiences and emotions. This brings about the development of certain kinds of personal and interpersonal awareness and sensitivity, the development of particular cultural knowledge and the acquisition of a set of skills, which taken together, form the basis for intercultural teaching. A learner's socio-cultural knowledge restricts how he realizes his linguistic potential. It would seem, therefore, that if a student has insufficient socio-cultural knowledge directly associated with the target language, he can hardly use the language accurately and appropriately and communicate effectively. Intercultural awareness in language teaching should be concerned with different viewpoints, and with allowing students to gain a perspective through comparisons of both cultures, and thereby acquiring ICC. According to Leigh (2001), the attempt to integrate cultural awareness in language teaching results in some problems for EFL teachers, for example, how to provide 
necessary information about cultural patterns, what to teach, and how to assess whether students are attaining their culturally-based goals. Moreover, most students find it difficult to realize that the teacher is striving to teach some aspects of the target language culture, since very often culture is not identified as a fundamental component of the syllabus.

Today, it is increasingly recognized that language learning and learning about target cultures cannot realistically be separated. In FL teaching the approach to testing culture is to test declarative knowledge of facts about the culture. Cultural understanding, however, includes understanding of daily life, knowledge of the cultural connotations of words and phrases, even the development of interest in or curiosity toward the target culture. Furthermore, literary texts can be very helpful in allowing students to acquire insight into a culture. It is generally recognized that the most effective way for students to learn about the target language and culture is to live for some time in the target community and to gain some insight into their family, professional, social lives, etc. As Walcott (2006) notes, cultivating ICC should be more than focusing a few lessons on holidays, dress, folk songs or food. Understanding the cultural context of day-to-day conversational conventions such as greetings, farewells, forms of address, thanking, making requests, giving or receiving compliments means more than just being able to produce grammatical sentences. It means knowing what is appropriate to say to whom, and in what situations, and it means understanding the beliefs and values represented by the various forms and uses of the language (Gulbinskienè - Lasauskienè, 2014).

A great deal of work has already been carried out by Russian researchers (Kitaygorodskaya, 1981; Bagramova,1993; Passov,1991; Polyakova, 1991; Zimnyaya, 2004; et al) the improvement of learning processes at universities through culture-based content and innovative educational technologies: Mikhanova (2004) has conducted extensive investigations in to the formation of universal competencies. The study of the professional communicative competence of future specialists was produced in 2008 by Kuznetsova.

The work of scholars in the field has laid down the theoretical and methodological foundations for much research focusing on modern approaches to EFL teaching that allow the formation of ICC (Leontiev,1969; Kitaygorodskaya, 1981; Khaleeva, 1989; Passov, 1991; Safonova, 1996; Bim, 2001; Zimnyaya, 2004; Milrud, 2013). A culturally-based approach to the organization of EFL teaching in schools and universities has been reported by many eminent Russian researchers (Passov, 1991; Safonova - Ter-Minasova, 2000) who identify a qualitatively new approach to the formation of foreign language intercultural competence in the context of both a linguistic and non-linguistic higher school.

However, if we exclude the early studies of Canale and Swain (1980), the relationship between learning a foreign language and ICC has not been not examined in the work of most methodologists. In applied linguistics some attempts have been made to consider the didactic construct of communicative competence within the framework of mastering a foreign language (Bachman,1990), but attempts to build such a model were not related to the assessment of language level or to the methodological problems of FL teaching. Therefore, there still remains considerable ambiguity with regard to forming future specialists' ICC in the process of FL teaching at a non-linguistic higher school.

\section{Materials and Methods}

\subsection{Research methods}

The present study has been undertaken as part of a fundamental study of the pedagogy ICC. The following methods have been used in our research: assessment of 
the key pedagogical principles of ICC, survey data analysis, evaluation of educational outcomes, interviews, systematization and categorization of facts and concepts.

\subsection{Research Stages}

The research was conducted in three stages.

The first stage involved: studying previous research; defining the subject matter, scope and purpose of the research; developing a hypothesis; formulating research objectives; defining methods appropriate to the purpose and objectives of the study; describing and justifying the structure and content of ICC; identifying research facilities.

In the second stage we conducted the survey data analysis to gain an insight into ICC among EFL students in a non-linguistic higher school. We selected and developed teaching materials for the implementation of ICC. The model for the formation of ICC among students majoring in Economics in an English language learning environment was theoretically justified, developed and assessed. The technology was developed for the implementation of the model presented.

The third stage included implementation of the model for the formation of ICC among students majoring in Economics in an English language learning environment; systematization and analysis of the results obtained; drawing conclusions.

\section{Results and Discussion}

The purpose of this research paper was the formation and assessment of students' ICC

To carry out the research on ICC, three research questions were formulated:

1. What methods are used to assess students' level of ICC?

2. What main blocking factors affect the cultivation of students' ICC?

3. What ways and means can be used to strengthen ICC through improvements in EFL teaching?

A survey was used in order to get an insight into the ICC of students majoring in Economics. A questionnaire was developed by EFL teachers and distributed among 50 first-year students majoring in Economics, taking classes in English, and studying International Finance at the Financial University under the Government of the Russian Federation.

The questionnaire contained 10 items, seven of which were designed to investigate students' contacts with foreigners/other cultures and the other three inquired about cultural awareness skills, and understanding similarities and differences between cultures. We asked students to choose an appropriate option that reflects their attitude towards ICC and learning experience:

Table 1: Questionnaire to identify awareness of ICC

\begin{tabular}{|c|c|c|c|c|c|}
\hline № & Questions & YES & NO & NOT SURE & $\begin{array}{c}\text { ANY OTHER } \\
\text { OPTIONS }\end{array}$ \\
\hline 1 & $\begin{array}{l}\text { How can you define the } \\
\text { term 'intercultural } \\
\text { communicative } \\
\text { competence'? }\end{array}$ & & & & \\
\hline 2 & $\begin{array}{l}\text { Can you foresee } \\
\text { possible cultural } \\
\text { barriers in business } \\
\text { communication? }\end{array}$ & & & & \\
\hline 3 & $\begin{array}{l}\text { Are you aware of } \\
\text { particular methods of } \\
\text { overcoming cross- } \\
\text { cultural }\end{array}$ & & & & \\
\hline
\end{tabular}




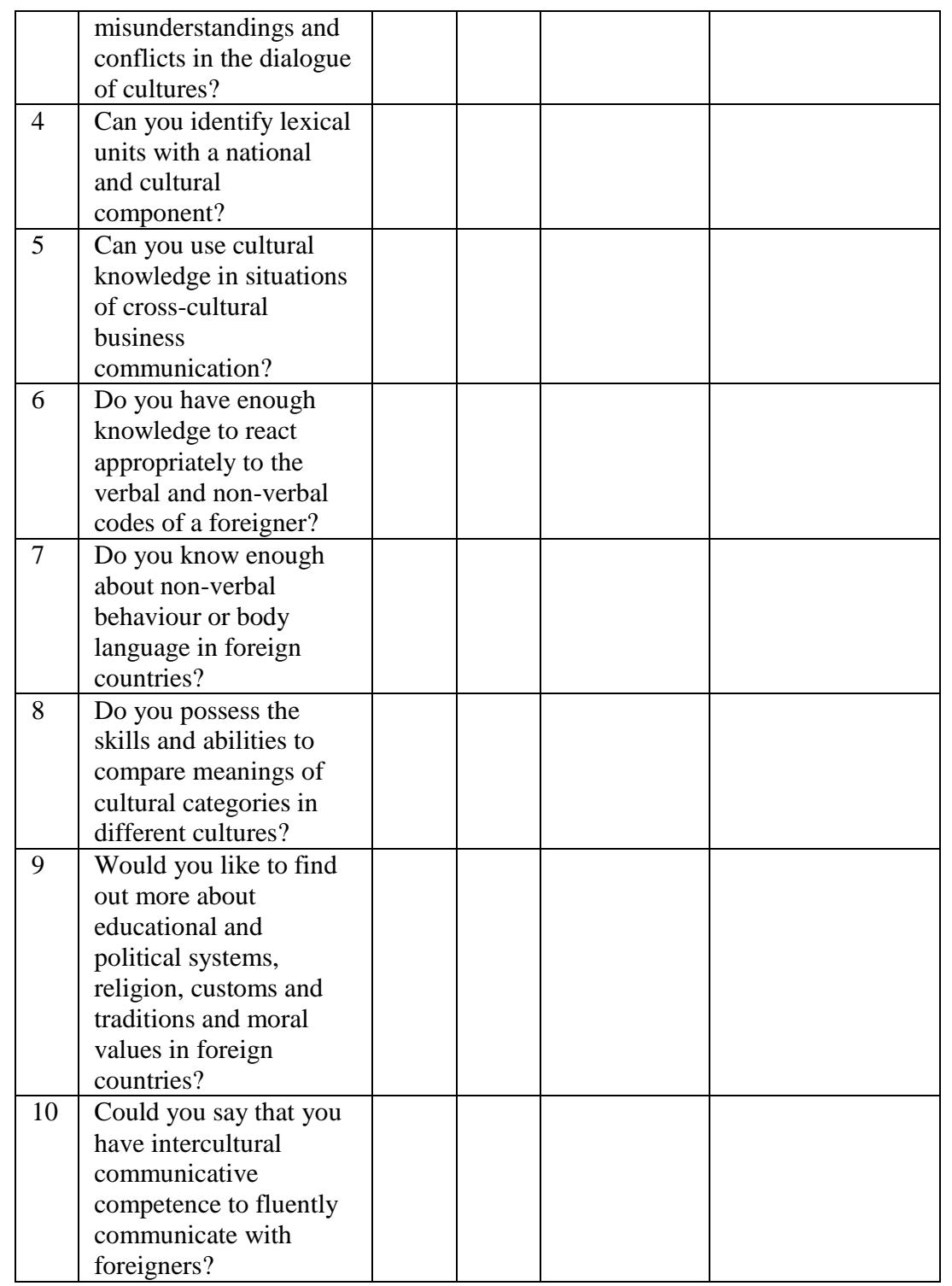

In developing ICC a person has to go through different stages from awareness, through acquiring knowledge and skills, to being motivated to apply intercultural skills in the process of multinational communication.

The students' answers to the first question reveal the fact that in the process of communication they do not take intercultural aspects into account. More than $75 \%$ of students define ICC as a high level of foreign language knowledge or the ability to communicate fluently in a foreign language. Students tend to ignore the need to develop the skills which are important for effective cross-cultural communication. However, $16 \%$ of students define ICC as showing understanding of the need to learn a 
foreign language culture. The other $9 \%$ of respondents are aware of the need to use relevant cross-cultural knowledge when taking part in cross-cultural communication.

The figures below illustrate the EFL students' answers to some of the questions which in our opinion best reveal their awareness of ICC.

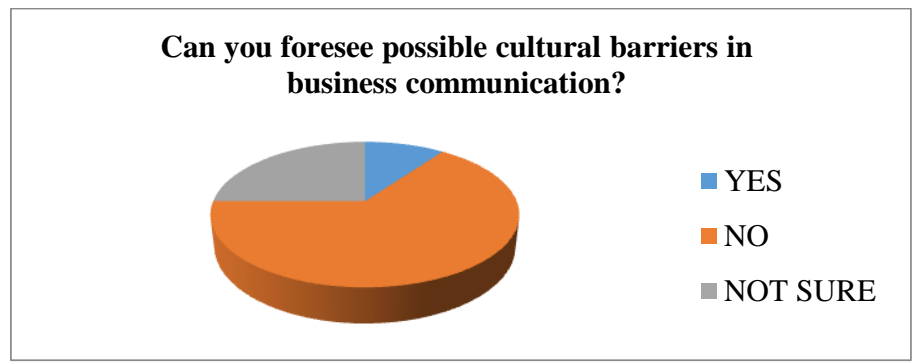

Figure 1: Students' answers for Question 1

As can be seen, $65 \%$ of students did not foresee possible cultural barriers in business communication and $25 \%$ of respondents were not sure about this due to the fact that first-year students as a rule lack theoretical and practical knowledge in the field of business communication. The remaining $10 \%$ showed little awareness of cultural differences and this strongly suggests that special materials should be designed to improve awareness among students majoring in Economics.

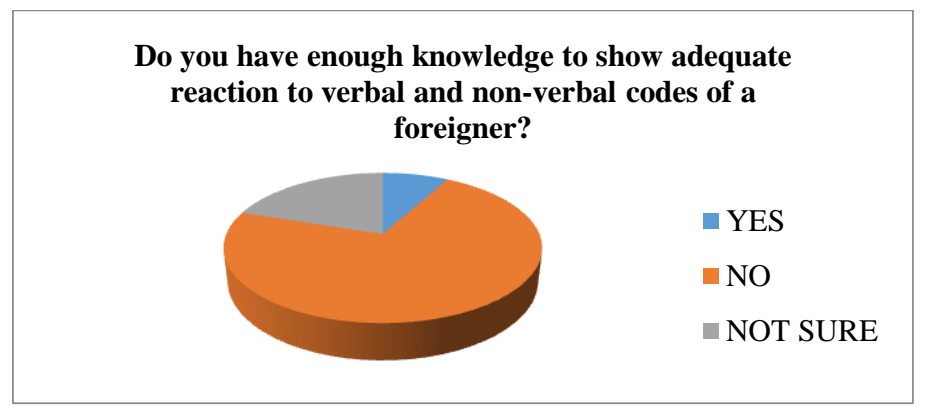

Figure 2: Students' answers for Question 2

Fig. 2 illustrates results very similar to those presented in Fig. 1. In answering the question concerning adequate reaction to the verbal and non-verbal codes of a foreigner, only $8 \%$ of students are sure that they will manage this situation. $72 \%$ responded negatively. The remaining $20 \%$ were not confident about this issue. This result suggests that English Language teaching is too narrow in its concerns to take full account of non-verbal communication. We support the approach presented by Poyatos (1992) that language teachers should be concerned with the "the triple reality of speech (language, paralanguage and kinesics)"and that these should be seen within a broader context of cultural signs of all kinds (https://books.google.ru/books?id=0vfq8JJWhTsC\&hl=ru\&source=gbs_navlinks_s). 


\section{Would you like to find out more about educational and political systems, religion, customs and traditions and moral values in foreign countries?}

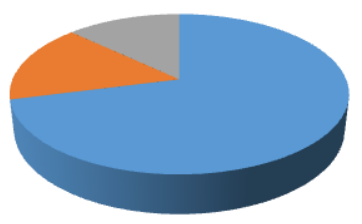

\section{Figure 3: Students' answers for Question 3}

In relation to the issue of educational and political systems, religion, customs and traditions and moral values in foreign countries, as can be seen in Fig. 3, the survey findings revealed that the majority of respondents $(71 \%)$ would like to find out more about these spheres. Only a small number of the students questioned (16\%) are not interested in finding out more about these areas of culture or are not sure if they are willing to explore them $(13 \%)$.

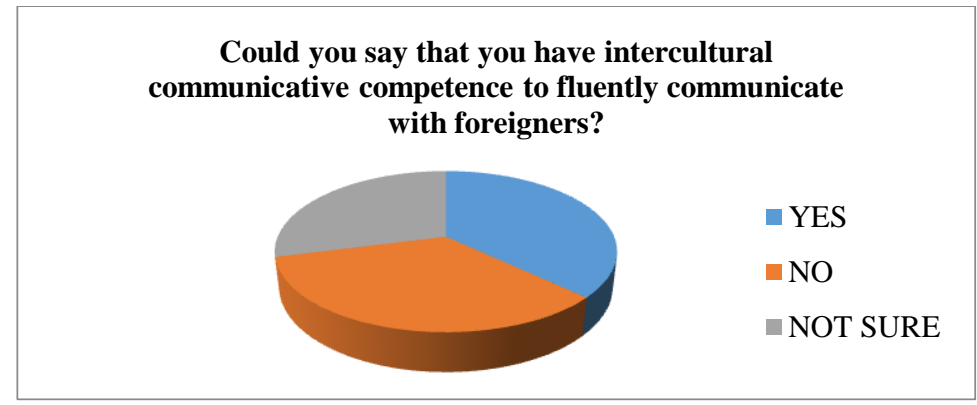

Figure 4: Students' answers for Question 4

Despite the fact that a low percentage of first-year students can foresee possible cultural barriers in business communication and show an adequate reaction to verbal and non-verbal codes of a foreigner, Fig. 4 shows that there is a slight difference in the number of the students surveyed who think that they have ICC to fluently communicate with foreigners $(37 \%)$ in comparison with the number who think the opposite $(34 \%)$ or are not sure $(29 \%)$.

Thus the research has shown that the students are aware of the advantages of cultural knowledge. However, the survey has revealed that students majoring in Economics at the Financial University under the Government of the Russian Federation still feel a lack of ICC.

To ensure the reliability of the study, in addition to quantitative data we decided to use qualitative data drawn from interviewing first-year students to get information on their attitudes towards ICC. The main themes of interviews were: contacts with foreign cultures, barriers to students' experience, teaching materials used to meet the needs of students' cultural learning, the actual state of ICC teaching.

The results have shown that most students have few opportunities for contact with foreign cultures. Just 15 students out 50 have had a chance to communicate with foreigners studying abroad. To some extent this increased their confidence in communicating with foreigners. However, they admitted the fact that 
they felt nervous socialising with foreigners. The main obstacles that EFL learners face when communicating with foreigners are: problems with vocabulary, and lack of listening and speaking skills. Moreover, students are not satisfied with the fact that although all the classes are in English, their teachers are not native speakers, and they are more focused on teaching language and theory rather than giving cultural background knowledge. Teaching materials do not meet the needs of the learners. Although a number of foreign films and videos are shown to the students, and authentic texts are used, they do not remember any cultural factors illustrated in the films, videos and texts due to lack of guidance. EFL learners pointed out the lack of intercultural communication experience and self-study activities.

To resolve these problems we decided to implement an intercultural componentin addition to the linguistic one on the FL course to extend students' horizonsin terms of ICC, and to help students acquire sensitivity to differences in behaviour, attitudes and values of people from other cultures. The main objectives of the course are as follows:

- Improving the components of ICC: skills and knowledge in the field of professional intercultural communication for the purpose of carrying out professional activities at an international level and self-fulfilment for continuing education in the second and third cycles

- Developing the ability to work in a team, tolerantly perceiving social, ethnic, interpersonal and cultural differences

- Developing readiness for self-education, cultivating the desire for selfimprovement in the ever-changing multilingual, multicultural world, increasing mobility and flexibility in solving professional problems

- Developing public speaking skills to do business and conduct professional dialogues in the process of intercultural communication

- Evolving skills to meet the expectations of the counterpart, to be effective in achieving communicative goals

- Teaching cultural aspects, native speakers' habits, traditions, norms of behavior and etiquette;

- Expanding knowledge to take professional decisions using a foreign language, which will increase the employability of the University's graduates in accordance with the demands of the labour market

- Training skills to identify cultural diversity and develop empathy

The process of gaining and evaluating ICC is quite complex. It requires certain attitudes, knowledge and skills to be promoted, in addition to learners' linguistic, sociolinguistic and discourse competences.

On the basis of data collected from the literature we identified the following components of ICC to be developed within the course.

\section{Table 2: ICC dimensions developed within the course}

\begin{tabular}{|c|c|c|}
\hline Knowledge & Skills & Awareness \\
\hline The structure & Communication skills & ntity (e.g., \\
\hline written and spoken & Dealing with different & ender, age, \\
\hline language; logical & onal situation & etc.). \\
\hline construction of sentences & Cooperating with & Cultural diversity. \\
\hline and utterances. & others. & Ethical dilemmas and \\
\hline $\begin{array}{l}\text { Language material } \\
\text { (vocabulary, grammar, } \\
\text { linguistic models) at the }\end{array}$ & $\begin{array}{l}\text { Problem solving and } \\
\text { stress management skills. } \\
\text { Critical thinking. }\end{array}$ & $\begin{array}{l}\text { their resolutions. } \\
\text { Cultural values and } \\
\text { ethics. }\end{array}$ \\
\hline level determined by the & Negotiation. & Cultural styles and \\
\hline Council of Europe as B1- & ntation skills. & language use. \\
\hline C1. & Research and analytical & Level of ICC. \\
\hline
\end{tabular}




\begin{tabular}{|c|c|c|}
\hline $\begin{array}{l}\text { Basic and complex } \\
\text { grammatical } \\
\text { constructions, complex } \\
\text { lexemes, such as phrasal } \\
\text { verbs for reception and } \\
\text { production. } \\
\text { Cultural styles and } \\
\text { language use, and their } \\
\text { effect on social and work } \\
\text { situations } \\
\text { Essential norms and } \\
\text { taboos of different } \\
\text { cultures (e.g., greetings, } \\
\text { dress, behaviours, etc.). } \\
\text { Important historical } \\
\text { and socio-political factors } \\
\text { of different cultures. } \\
\text { Various behavioural } \\
\text { patterns of different } \\
\text { cultures. }\end{array}$ & $\begin{array}{l}\text { skills. } \\
\text { Skills in written and } \\
\text { oral communication } \\
\text { (selection of appropriate } \\
\text { lexical units in certain } \\
\text { business communication } \\
\text { situations). } \\
\text { Understanding } \\
\text { information when reading } \\
\text { educational or scientific } \\
\text { literature for a specific } \\
\text { purpose. } \\
\text { Understanding texts of } \\
\text { different levels } \\
\text { difficulty. } \\
\text { Taking an active part in } \\
\text { discussions on different } \\
\text { issues, taking into account } \\
\text { social, ethnic, religious } \\
\text { and cultural differences. } \\
\text { Use of Internet } \\
\text { resources to extract } \\
\text { information in the foreign } \\
\text { language for educational } \\
\text { and scientific purposes. }\end{array}$ & $\begin{array}{l}\text { Differences and } \\
\text { similarities across } \\
\text { different languages and } \\
\text { cultures. }\end{array}$ \\
\hline
\end{tabular}

Considering the dimensions presented and the results of the questionnaire, we discussed the following topics within the course:

- International companies. Communication with foreign partners. European and Asian styles of communication.

- International Business Cooperation with European companies. Working with Chinese partners.

- Doing business in India. Importance of understanding the specifics of local cultures.

- Mergers of international companies. Positive and negative experience of mergers of international companies.

- Foreign business trips. Responsibilities, difficulties and prospects of working abroad.

- Working in an international team. International virtual business and its peculiarities. Taking part in international

projects and programs. Studying abroad. Skills necessary for the CEO of an international company.

The classroom may be the only place where students can freely discuss the cultural encounters they have experienced with a native member of the culture. Also, the teacher can help give students tools for understanding basic cultural differences that can then be applied to situations encountered outside the classroom. Moving towards competence-based education brings benefits to both students and teachers (Kalugina, 2016: 38). To develop interest and curiosity toward different cultures, we have to agree on appropriate interactive classroom activities and self-study tasks.

To explore possible classroom activities and self-study tasks we included a questionnaire with 3 multiple-choice questions addressed to 50 first-year students and 20 English teachers. The findings are presented below. 
Table 3: Interactive classroom activities teachers should employ to cultivate ICC

\begin{tabular}{|c|c|c|c|c|c|c|}
\hline \multirow[b]{2}{*}{ Interactive classroom activities } & \multicolumn{2}{|c|}{$\begin{array}{l}\text { Total } \\
\text { cases }\end{array}$} & \multicolumn{2}{|c|}{ Subcases } & \multicolumn{2}{|c|}{$\begin{array}{l}\text { Percentage } \\
(\%)\end{array}$} \\
\hline & 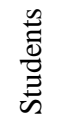 & 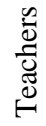 & $\begin{array}{l}\stackrel{0}{0} \\
\stackrel{0}{E} \\
\text { 苟 }\end{array}$ & $\frac{\mathscr{E}}{\mathscr{E}}$ & 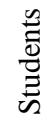 & 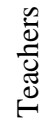 \\
\hline A. Scientific discussions & \multirow[t]{6}{*}{50} & \multirow[t]{6}{*}{20} & 5 & 2 & 10 & 10 \\
\hline B. Analysis of case studies & & & 14 & 3 & 28 & 15 \\
\hline C. Role play & & & 11 & 4 & 22 & 20 \\
\hline D. Debate & & & 7 & 2 & 14 & 10 \\
\hline E. Scientific presentations & & & 6 & 4 & 12 & 20 \\
\hline $\begin{array}{l}\text { F. Review of scientific literature on } \\
\text { the topics studied }\end{array}$ & & & 7 & 5 & 14 & 25 \\
\hline
\end{tabular}

Table 4: Self-study tasks which should be used to develop ICC

\begin{tabular}{|c|c|c|c|c|c|c|}
\hline \multirow[b]{2}{*}{ Self-study tasks } & \multicolumn{2}{|c|}{ Total cases } & \multicolumn{2}{|c|}{ Subcases } & \multicolumn{2}{|c|}{$\begin{array}{l}\text { Percentage } \\
(\%)\end{array}$} \\
\hline & $\frac{\mathscr{E}}{\stackrel{\tilde{U}}{\tilde{E}}}$ & 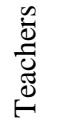 & 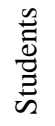 & 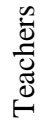 & 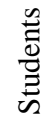 & 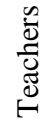 \\
\hline A. Brainstorming & \multirow[t]{6}{*}{50} & \multirow[t]{6}{*}{20} & 2 & 2 & 4 & 10 \\
\hline B. Essay writing & & & 6 & 4 & 12 & 20 \\
\hline C. Interviews & & & 4 & 2 & 8 & 10 \\
\hline $\begin{array}{l}\text { D. Doing exercises from textbooks } \\
\text { targeted at ICC training }\end{array}$ & & & 22 & 7 & 44 & 35 \\
\hline E. Making dialogues & & & 9 & 3 & 18 & 15 \\
\hline F. Listening activities & & & 7 & 2 & 14 & 10 \\
\hline
\end{tabular}

Table 5: Main ways to enhance EFL learners' ICC

\begin{tabular}{|c|c|c|c|c|c|c|}
\hline \multirow[b]{2}{*}{ Main ways } & \multicolumn{2}{|c|}{$\begin{array}{c}\text { Total } \\
\text { cases }\end{array}$} & \multicolumn{2}{|c|}{ Subcases } & \multicolumn{2}{|c|}{$\begin{array}{c}\text { Percentage } \\
(\%)\end{array}$} \\
\hline & 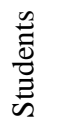 & 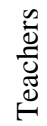 & 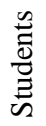 & 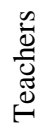 & 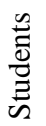 & 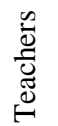 \\
\hline A. Being taught by foreign teachers & \multirow[t]{6}{*}{50} & \multirow[t]{6}{*}{20} & 22 & 3 & 44 & 15 \\
\hline B. Studying abroad & & & 14 & 2 & 28 & 10 \\
\hline C. Paying more attention to self-study & & & 7 & 5 & 14 & 25 \\
\hline D. Improvement of teaching materials & & & 2 & 1 & 4 & 5 \\
\hline $\begin{array}{l}\text { E. Development of extra-curricular } \\
\text { activities to enhance EFL learners' } \\
\text { ICC }\end{array}$ & & & 2 & 8 & 4 & 40 \\
\hline F. Usage of the Internet & & & 3 & 1 & 6 & 5 \\
\hline
\end{tabular}


As shown in the tables above, the researchers found that the views of the teachers and the writers of interactive classroom activities, self-study tasks and other materials designed to enhance EFL learners' ICC and the views of students are different. Most of the teachers think that students can improve their ICC through reviews of literature on the topics studied and presentations, while students consider interactive class activities such as analysis of case studies and role plays to be more effective. $35 \%$ of teachers chose the option "doing exercises from the textbooks targeted at ICC training as a priority. The students surveyed (44\%) did not share this position. However, the respondents had the same opinions on the main ways to enhance EFL learners' ICC: the teachers as well as the students believe that doing exercises from the textbooks targeted at ICC training will help students acquire effective intercultural communication skills.

The next stage was designing a textbook for self-study with a highly customized body of content. The textbook contains assignments and exercises focused on the development of ICC that are aimed at developing skills of independent work, self-discipline and preparation for an achievement test. The textbook is contextspecific and the materials used in the textbook are drawn from authentic sources. It is not just a collection of texts drawn from different genres, it reflects a particular pedagogic point to encourage learners to apply their developing skills to the world beyond the classroom. Table 6 depicts the structure of the first unit.

\section{Table 6: The content of the first unit «Doing business in China»}

\section{LEAD-IN}

In LEAD-IN section students are given the excerpt from the book "Who owns the world?" by Chomsky, which introduces the theme of the unit and is used to activate students' prior knowledge of the topic. It contains two tasks:

Task 1 How do you understand the term "an assembly plant" in manufacturing? Do you think that's an export from China if, say, you buy an i-product - for example, an iPad-from China, but the parts and components and technology come from outside China?

Task 2 Complete the statements in the quiz about China.

Examples:

1. The Chinese prefer business communication ...
A by phone
C by business letters
B by email
$\mathrm{D}$ face to face

2. A handshake in China should be ...
A limp and brief
C firm but brief
B strong and lengthy
E firm

\section{BEFORE YOU READ}

BEFORE YOU READ section covers a range of questions, all directed at helping EFL learners engage in the process of discovery and to feel authorized to engage with the form and the content of the text.

Task 3 Discuss the questions

\section{READING}

In the READING section students are given the article «China's uncannily strong economy» from the authentic sources. It covers economic issues touching upon cultural pecularities of doing business in China. This text develops EFL learners' intercultural communicative competence as the language and intercultural awareness are interrelated. The tasks in the reading section measure the EFL learners' ability to understand economic passages (Task 4, 5), enrich the vocabulary which is relevant to the learners' field of study (Task 6) and enhance students' writing skills.

XLinguae, Volume 10 Issue 4, October 2017, ISSN 1337-8384, eISSN 2453-711X 
Task 4 Read the article about uncannily stable economic growth in China and say whether these statements are true $(\mathrm{T})$, false $(\mathrm{F})$ or there is not enough information given (NG).

Task 5 Read the article again and answer the questions.

Task 6 Complete the crossword puzzle with words from the article.

Task 7 Write a review of the article using useful phrases in Appendix 1.

Language and intercultural communication are inseparable. Within the framework of the intercultural approach, the main task of language education is positive development of the personality and self-awareness as a result of the acquisition of a foreign language and cultural experience (Vasbieva, Kalugina, 2016: $60)$.

While integrating these teaching materials into teaching practices we realised that the emphasis should be on the evaluation of current performance of ICC skills. This "current performance" is aimed at developing the level of ICC and enhancing the learning process. The facilitator will focus on the process of gathering information in order to identify strengths and weaknesses and compare them with the desired learning outcomes. Since summative evaluation normally sums up achievement at the end of a course with scoring, it is not appropriate for the assessment of ICC. Due to the fact that ICC covers behavioural and affective, as well as cognitive, domains, evaluation should be based more on a formative process to identify progressive levels of control in simulated situations. Furthermore, the evaluation process should be extensive: the teacher evaluates students, and students analyze their own speaking, written work and projects throughout the course. Assessment can be carried out using checklists filled in by the teacher and / or students, and portfolios (collection of students' work at different stages). In addition to the teacher's assessment; self-evaluation can be also an effective method (Kalugina, 2016).

\section{Conclusion}

Thus the study has highlighted the factors blocking ICC. It shows the importance and urgency of addressing and verbalising these issues in class as a part of the foreign language curriculum. The ICC of students majoring in Economics can be promoted if teachers and students pay more attention to the cultural dimension. It is essential to create a comfortable environment for ICC training. Moreover, selecting relevant interactive classroom activities, self-study tasks and teaching materials can contribute a great deal toward enhancing students' level of ICC. The effectiveness of ICC development depends in many respects on finding an optimal balance between students' needs and teachers' professional competence. Our investigations into this area are still ongoing. This research has thrown up many questions in need of further examination of ICC of students majoring in Economics.

\section{Bibliographic references}

ALYAN, A. 2011. The Intercultural Dimension in EFL University Context: EFL Teachers Beliefs regarding the Concepts of Culture. Saarbrücken: Lambert Academic Publishing. ISBN-10 3846536458.

ARUTYUNOVA, N.D. 1997. Language functions. Russian language: Encyclopaedia. Moscow. Available online: http//www.dissercat.com

BACHMAN, L. 1990. Fundamental Considerations in Language Testing.Oxford: Oxford University Press. ISBN: 978-0-19-437003-5.

BAGRAMOVA, N.V. 1993. Linguistic and metholodological bases of ESL teaching vocabulary for speaking in teacher's training institute. diss ... Doct. of Pedagogy. SPb. 
BIM, I.L. 2001. Some burning issues of modern foreign language teaching. In: Foreign languages at school, n.4, pp. 5-8.

BIROVA, J. - KLIMOVA, I.I. - KALUGINA, O. 2016. Some critics on language education assessment. Mathematics Education, vol. 11, n. 7, pp. 2470-2482. ISSN 2468-4945.

BROWN, H.D. 1986. Learning a second culture. In J. M. Valdes (Ed.), Culture Bound. New York, NY: Cambridge University Press, pp. 33-48. ISSN 0130-6073.

BYRAM, M. 1994. Teaching and Learning Language and Culture. Bridgend: WBC Ltd. ISBN 1853592110.

BYRAM, M. 1997. Teaching and Assessing Intercultural Communicative Competence. Clevedon: Multilingual Matters, 124 p. Available online: https://books.google.ru/books?id=0vfq8JJWhTsC\&hl=ru\&source=gbs_navlinks_s

CANALE, M. - SWAIN, M. 1980. Theoretical bases of communicative approaches to second language teaching and testing. In: Applied Linguistics, vol. 1, n.1, pp. 1-47.

CANALE, M. 1983. From communicative competence to communicative language pedagogy. In: Language and Communication / eds. by J.C. Richards, R.W. Schmidt. Harlow: Longman, pp. 2-27. ISSN: 0271-5309.

CANALE, M. 1984. A communicative approach to language proficiency assessment in a minority setting. In Rivera, C. (Ed.), Communicative Competence Approaches to Language Proficiency Assessment: Research and application, pp. 107-122. Clevedon: Multilingual Matters. ISBN 0-905028-22-8.

CHOMSKY, N. 1965. Aspects of the Theory of Syntax. Boston: MIT Press. ISBN 9785998950773.

DILLER, J.V. - MOULE, J. 2005.Cultural Competence: A Primer for Educators. Belmont, CA: Thomas Wadsworth Publishing. ISBN-10 0495915297.

ELIZAROVA, G.V. 2001. The formation of students' cross-cultural competence in the process of EFL teaching. diss... Doct. of Pedagogy. SPb. 371p.

GULBINSKIENE, D. - LASAUSKIENE, R. 2014. Intercultural Communicative Competence (ICC) of EFL Students at University Level. In: Man and the word, vol. 16, n. 3, pp. 150-159. ISSN 1392-8600.

HYMES, D. H. 1972. On communicative competence, in Pride, J. B. \& Holmes, J. (Eds.), Sociolinguistics, Harmondsworth: Penguin Books, 296-293.

KALUGINA, O. 2011. Development of Communicative Competence. Financial Research Institute.Financial Research, n.4, pp. 179-188. ISSN 2075-1990.

KALUGINA, O. 2016. The Assessment of Intercultural Communicative Competence. In: Science Review: Humanities Research, n. 9, pp. 55-58. ISSN 2226-0234.

KALUGINA, O. 2015. The Formation of Professional and Communicative Competency by Competency-Oriented Exercises (From the Experience of Teaching in a Non-Linguistic Institute of Higher Education). In: Philological Sciences. Issues of Theory and Practice, vol. 10, n. 52, pp. 103-106. ISSN: 1997-2911.

KALUGINA, O.A. 2016.Development of students' professional communicative competence in an economic higher school. In: XLinguae Journal, vol. 9, n. 4, pp: 37 45. ISSN 1337-8393.

KHALEEVA, I. I. 1989. Basics of theory of teaching to understand a foreign speech (interpreters' training). Moscow. 240 p.

KITAYGORODSKAYA, G.A. 1981. Psychological and pedagogical principles of the method of stimulating learner's potential: Stimulation of the teaching process. Moscow: Pedagogy, pp. 5-18.

KLIMOVA, I.I. - VASBIEVA, D.G. 2014. Development of students' foreign language intercultural professional competence in an economic higher school. Philological Sciences. Theory and practice of teaching foreign languages at a nonlinguistic university: Traditions, Innovations, Prospects: collection of papers. Moscow: Financial University, pp. 128-139. ISBN 978-5-7942-1236-5.

XLinguae, Volume 10 Issue 4, October 2017, ISSN 1337-8384, eISSN 2453-711X 
KRAMSCH, C. 1993. Context and Culture in Language Teaching. Oxford: Oxford University Press. ISBN-10 0194371875.

KUZNETSOVA, S.V. 2008. Formation of professional communicative competence of students majoring in Economics in the process of foreign language teaching: extended abstract ... Cand. of Pedagogy. Penza. p.26

LEIGH, J. W. 2001. Communicating for Cultural Competence. Long Grove, IL.: Waveland Press Incorporated. ISBN 9781577666820.

LEONTIEV, A.A. 1969. Language, speech, speaking activities. Moscow: Prosveshchenie. 214 p. ISBN: 978-5-396-00142-8.

MILRUD, R.P. 2013. Teaching as a managed and self-managed cognitive activity. In: Scientific dialogue: Pedagogy, vol. 2, n.14, pp. 33-48.

LUM, D. 2004. Cultural Competence, Practice Stages, and Client Systems: A Case Study Approach. Andover: Cengage Learning. ISBN - 10: 0534631983.

MIKHANOVA, O.P. 2008. Interactive methods of teaching as a means of forming competences. In: Izvestia of A. I. Gertsen's Russian State Pedagogical University, n. 58, pp. 427-432. ISSN 2306-9880.

PASSOV, E.I. 1991. Communicative method of foreign language teaching. Moscow: Prosveshchenie.222p.

POPOV, A.YU. 1998. Cross-cultural Contacts. Moscow. 83p. ISBN 5-09-000707-1.

SADCHIKOVA, Ya.V. 2009. Formation of intercultural competence of students in the process of learning a foreign language in a technical university: dis. ... Cand.of Pedagogy. Penza. 181 p. Available online: http://www.dissercat.com/content/formirovanie-mezhkulturnoi-kompetentnostistudentov-v-protsesse-obucheniya-inostrannomu-yazy\#ixzz4ogO0tiae

SAFONOVA, V.V. 1996. Learning foreign languages in the context of culture dialogues and civilisations. Voronezh: Istoki. 237p.

SAVIGNON, S. 1985. Evaluation of communicative competence: The ACTFL provisional proficiency guidelines. In: The Modern Language Journal, 59, pp. 129134. ISSN1540-478.

SEHLAOUI, A.S. 2011. Developing ESL/EFL Teachers' Cross cultural Communicative Competence: A Research-based Critical Pedagogical Model. Saarbrücken: Lambert Academic Publishing.

TER-MINASOVA, S.G. 2000.Language and Intercultural Communication. Moscow: Slovo. p.624 ISBN 978-5-387-00069-0.

TROSBORG, A. 1995.Interlanguage Pragmatics: Requests, Complaints and Apologies, Berlin: WalterdeGruyter.

VASBIEVA, D.G. - KALUGINA, O.A. 2014. Formation of foreign language intercultural competence as the component of professional communicative competence of Economics major students. In: Science Review: Humanities Research, n. 5, pp. 15-25. ISSN 2226-0234.

VASBIEVA, D.G. - KALUGINA, O.A. 2016. An Analysis of Students' Intercultural Competence Levels in a Non-Linguistic Higher School. In: XLinguae, vol. 9, n. 3, pp.58-69. ISSN 1337-8393.

VASBIEVA, D.G. 2015. Features of teaching cross-cultural communication in foreign language classes in non-linguistic higher education establishment. In: Philological Sciences. Issues of Theory and Practice, vol. 7, n. 59, pp. 40-42. ISSN 1997-2911.

VYAS, M.A. - PATEL, Y.L. (Eds.). 2009. Teaching English as a Second Language: A New Pedagogy for a New Century. New Delhi: PHI Learning Private Limited.

VYGOTSKY, L.S. 1992. Thinking and speech. Moscow: Labirint. 352 p.

WALCOTT, W. H. 2006. Knowledge, Competence, and Communication: Chomsky, Freire, Searle, and Communicative Language Teaching. Montreal: BlackRose Books. WALCOTT, W.H. 2001. Radical Pedagogy. Knowledge, Competence and Communication. ISSN 1524-6345. 
ZIMNYAYA, I.A. 2004. Key competences as effectively target basis of competency approach in education, Moscow: Research Centre for the Problems of Quality in Specialists' Training. $42 \mathrm{p}$.

Words: 7100

Characters: 48478 (36,93 standard page)

Alan Pulverness

Senior Consultant

Norwich Institute for Language Education

78-80 Upper St Giles Street

Norwich NR2 4PG

United Kingdom

alan@nile-elt.com

Prof. Irina I. Klimova, PhD.

Assoc. Prof. Olga A. Kalugina

Assoc. Prof. Dinara G. Vasbieva, PhD.

Department of Foreign Languages

Financial University under the Government of the Russian Federation

Leningradsky prospect 49

125993 Moscow

Russia

iiklimova@mail.ru

kaluginaruc@mail.ru

dinara-va@list.ru

Assoc. Prof. Liliya R. Ismagilova, PhD.

Foreign Language Department in the Sphere of Economy, Business and Finance

Kazan (Volga region) Federal University

18 Kremlyovskaya Street

420008 Kazan

Russia

lilia.ismg@gmail.com 